\title{
Preliminary Report on an Archeological Survey of Stormy Point
}

Jim Hardey

Unknown

Claude McCrocklin

Follow this and additional works at: https://scholarworks.sfasu.edu/ita

Part of the American Material Culture Commons, Archaeological Anthropology Commons, Environmental Studies Commons, Other American Studies Commons, Other Arts and Humanities Commons, Other History of Art, Architecture, and Archaeology Commons, and the United States History Commons

Tell us how this article helped you.

This Article is brought to you for free and open access by the Center for Regional Heritage Research at SFA ScholarWorks. It has been accepted for inclusion in Index of Texas Archaeology: Open Access Gray Literature from the Lone Star State by an authorized editor of SFA ScholarWorks. For more information, please contact cdsscholarworks@sfasu.edu. 


\section{Preliminary Report on an Archeological Survey of Stormy Point}

Creative Commons License

(c) $)(1)$ (9)

This work is licensed under a Creative Commons Attribution-NonCommercial 4.0 International License 


\section{PRELIMINARY REPORT ON AN ARCHEOLOGICAL SURVEY OF STORMY POINT}

Jim Hardey and Claude McCrocklin

This is a report on an archaeological survey of the point of land that extends south into Caddo Lake opposite Mooringsport, Louisiana. The nineteenth century name for this area was Stormy Point, and the area into which Stormy Point extends was called Ferry Lake in 1839 (Figure 1). The primary purpose of the survey was to find eighteenth century and early nineteenth century Caddo Indian sites, with the focal point of the survey being the thirty acre southwest tip of the point; other areas were looked at but not thoroughly investigated. Prehistoric Indian and early Anglo-American sites found while surveying for the Historic Caddo sites will also be reported.

\section{Landscape}

The sandy 10 meter high southwest end of Stormy Point is a grass-covered area with a fringe of trees and brush along the west bank. The extreme south tip of the point to the water's edge is covered with large trees and dense undergrowth. The top of the point is more open with some trees and clumps of briars and brush. Occasional palmettoes, cactus, and cedar trees dot this area, and several large walnut trees are along the bluff edge.

There are several moderate to large-size shallow depressions on the west side of the area. One of these could be the remains of Colonel Pitts' cellar (see below). The others are probably oil field related depressions as there is a heavy scatter of oil field material all over the point. Power and pipe lines cross the point from east to west with the right-of-way for each cutting through the west bank to the water's edge. The east cut gives a good profile of the point's stratigraphy and reveals that the sandy soil averages one to two meters in thickness. To the north of the site area is a large forty acre field that used to be cultivated. No extant features other than the power line are on the west side of the point.

The impression one gets while standing on Stormy Point is that it is an unusual place. The high overlook of Caddo Lake with water on three sides is beautiful, and one can appreciate why the Indians from Paleo-Indian times to the Historic Caddo period would have chosen to live there. Later, Anglo-American settlers built their homes there for the same reasons; there are no single component sites found to date on Stormy Point. 


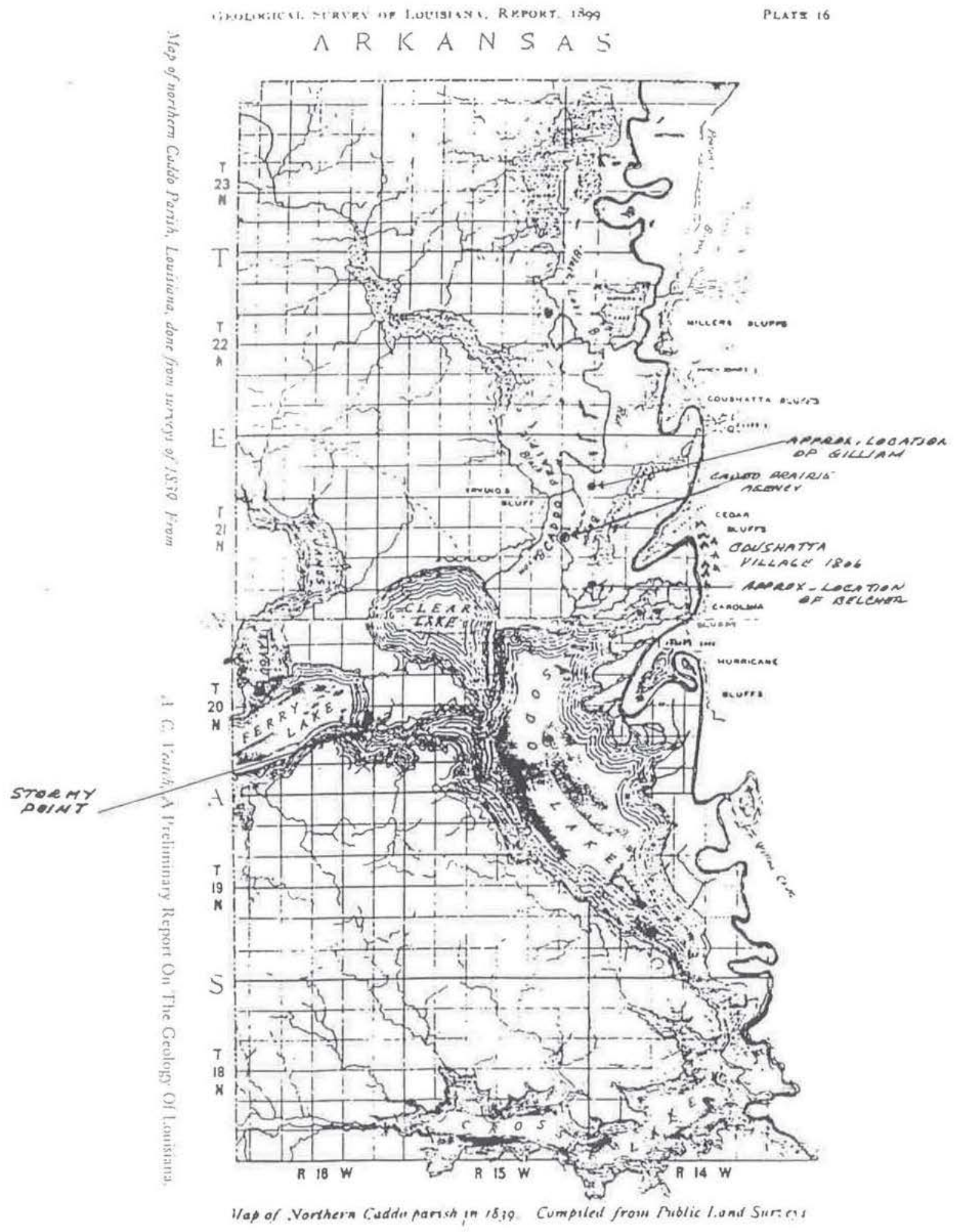

Figure 1. Map of Northern Caddo Parish, Louisiana, done from surveys of 1839 (From Veatch and Harris 1899) 
History

A remarkable account of the nineteenth century Caddo Indian history of Stormy Point is given in the document A Geological Report on Northern Caddo Parish in 1899. This report is part of Veatch and Harris's Geological Survey of Louisiana, 1899. The discussion of Stormy Point, Ferry Lake is as follows:

A cellar dug near the end of Stormy Point by Col. S.D. Pitts in 1885, disclosed quite an amount of pottery at a depth of from four and one-half to five feet. One large pot, when found, was full of living ants, evidently attracted there by something the pot contained. A smaller pot was filled with children's bones. An iron tomahawk, two iron rifle barrels and an iron knife about eight inches long were also found.

About 1870 high water washed out the bluff on the southwestern corner of the point and exposed a skeleton. The forehead was covered with a thin highly ornamented piece of silver bent to fit the skull. On the back of the head was a circular piece of silver. These pieces are said to have been analyzed by a local jeweler and pronounced virgin silver. On the shoulders were thin crescent shaped pieces of metal. They were described as having been coated with green, and are hence inferred to have been copper.

The son-in-law of Larking (sic) Edwards, the interpreter and friend of the Caddoes, "Old James Shemick", from whom the place was bought, stated several years before the skeleton was found that the last chief of the Caddoes was buried somewhere in that vicinity.

This point was a favorite place for the collecting of the Caddo Indians when they desired to start for Shreveport. They crossed the lake at Newport point and their trail from there to Shreveport is said to have been quite visible as late as 1860 .

Stormy Point was also the place where the Caddo Indians were to receive the final installment payment for their lands sold in 1835, and from where James Shemick (or Shenix) operated a ferry across Ferry Lake in 1840 (From testimony of Larkin Edwards before Robert Marye, Justice of the Peace, at Shreveport on the 16th of December 1840 [O'pry 1928:77-78]).

\section{Methods}

The survey methods used were surface collecting, test excavation and screening with a 1/4-inch hardware cloth, metal detector scans, and probes with a steel rod. The most effective of these were surface collecting and test excavations. The metal detector scans were largely ineffective due to the heavy subsurface scatter of old oil field debris, such as pipe fittings, nuts, bolts, washers, etc. Some of this litter was eliminated by setting the detector on maximum discrimination. This eliminated small iron objects, but detected the lead musket balls, copper trade material, and other nonferrrous metal artifacts present on the site. A Pelorus compass and a range finder calibrated in meters was used to plot the site location and areas where artifacts were recovered. 


\section{Site Description}

There is a site along the entire south end of Stormy Point. Artifacts and cultural materials dating from prehistoric times to early twentienth century oil field related activity may be found, but due to the heavy vegetation, there are very few places where artifacts may be seen on the surface. These are in the dirt roads, where the bluff edge has eroded or has been disturbed, and along the shoreline.

The most prominent features on top of the point are the remains of old chimney falls where the early Anglo-American settler's houses stood. These are marked by dense concentrations of fragmented hand-made brick, broken glass and ceramics, and nails. There are two of these sites, one in the center of the ridge just south of the power line, and another on the southwest bluff line near the east right-of-way cut. They are both mid-to-late nineteenth century sites, with the one in the center of the point appearing to be the older of the two. A third and earlier house site is believed to have eroded off the southwest edge of the point. Older material, such as eighteenth and early nineteenth century European ceramic sherds, dark green wine bottle glass, thin $(2 \mathrm{~mm})$ window glass, gun flints, large caliber musket balls, and square nails are scattered from just below the bluff to the water's edge. At high water, quantities of this material is washed out by wave action and can be collected along the shoreline. Occasional Caddoan ceramic sherds are found among this European material, but their age is uncertain due partly to our lack of knowledge of just what types of pottery to expect on nineteenth century Caddo sites.

\section{Prehistoric and Historic Sites}

Early to middle Archaic lithic materials were found along the shoreline and in washed out areas along the bluff edge. Dart points found ranged from Early Archaic San Patrice points to corner-notched and side-notched Middle Archaic types. Knives, scrapers, grinding stones, and numerous flakes and chips were also found along the shore. On top of the point, nickel and quarter-sized Caddo ceramic sherds are found scattered over the surface along with an occasional arrowpoint.

Of the two historic house sites on top of the point, the one in the center area appears to be older in age. This could be the house site of James Shemick (or Shenix?); the artifacts from the test excavations and surface collecting tend to indicate this as the hand-made brick from the chimney fall is soft, almost daub-like, and the European ceramic sherds are of early nineteenth century age. Glass, buttons, square nails, and other small artifacts belong mostly to an early to mid-nineteenth century component, while the later material scattered over the site is attributed to early twentieth century oil field activity. 
The house site on the southwest edge of the point appears to be of late nineteenth century age. Close to the east side of the site is a large depression. It has oil field pipe in it now, but it looks as if the depression was already there when the oil field people enlarged it. This is based upon the results of excavating and screening the heaped-up dirt around the depression. Horse shoes, wagon fittings, square nails, glass, ceramic sherds, thin sheet copper, and Indian lithics were found in this fill dirt. This depression could mark the site of Colonel Pitts' house and cellar.

The early nineteenth century material below the bluff to the shoreline is an enigma since no existing concentration on the point can be associated with it. The most probable explanation is that the area from which it derived crumbled off the top of the point sometime in the past. This is substantiated by the abraded surfaces and rounded edges of the ceramic sherds and the fragments of glass found in this area. High water wave action buffeting the material with the natural iron ore gravel on the beaches would cause these types of wear. In contrast, if the material was coming from the lake bottom and washing up on the beach, at least some of the newly arrived sherds would still have sharp, crisp edges.

The origin of the prehistoric Indian material found on the shoreline likewise cannot be determined. Some of the dart points, like the historic materials, are worn smooth while others have sharp surfaces as if just washed up from out in the lake. Since none of the area below the bluff has any stratigraphic integrity, we will probably never know the origin of any of this prehistoric or historic material.

\section{Comments}

Although we did not find a single component nineteenth century Caddo Indian site in our investigations, we did find enough evidence through research and field tests to substantiate that one is there at Stormy Point. We did find enough archaeological material, both prehistoric and historic in age, to justify a continued investigation of Stormy Point. The two early nineteenth century Anglo-American house sites alone would be worth excavations. In this respect, our survey of Stormy Point was a success, and thus the data recorded should be of use to archaeologists who would want to do a more detailed study of the site.

\section{Acknowledgments}

Our thanks to Mr. W.C. "Dub" Allen and sons who own the land and who kindly gave us permission to do the survey. We thank Mrs. Coe Haygood of the Caddo-Pine Island Historic and Oil Museum at Oil City, Louisiana for providing research material and 
assisting us in our study of it. Jim Hardey was field director for the survey and Ms. Ruth Rainey kept the survey records. Both did valuable research work for the project.

\section{References}

O'pry, Maude Hearne

1928 Chronicles of Shreveport and Caddo Parish. In Caddo Cession, pp. 6478. Shreveport.

\section{RECENT PUBLICATIONS}

Davis, Hester A. (editor)

1991 Arkansas before the Americans. Arkansas Archeological Survey, Research Series No. 40. vi +152 pp.

Fox, Anne A.

1991 An Overview of Spanish Archaeology in Texas. Papers on Latin America, Pre-publication Working Papers of the Institute of Latin American Studies, Paper No. 91-04. 15 pp. University of Texas at Austin.

Lists of titles and available publications of the Institute of Latin American Studies can be obtained by writing: Publications, Institute of Latin American Studies, SRH 1.310, University of Texas, Austin, Texas 78712.

Jackson, Jack, Robert S. Weddle, and Winston DeVille

1990 Mapping Texas and the Gulf Coast: The Contributions of SaintDenis, OLivan, and LeMaire. Texas A7M University Press, College Station. xi + 92 pp.

Klesert, Anthony L. and Alan S. Downer (editors)

1990 Preservation on the Reservation: Native Americans, Native American Lands, and Archaeology. Navajo Nation Papers in Anthropology No. 26. Navajo Nation Archaeology Department and Navajo Nation Historic Preservation Department, Window Rock. ix +490 pp.

Paredes, J. Anthony (editor)

1992 Indians of the Southeastern United States in the Late Twentieth Century. University of Alabama Press.

Parker, Patricia L.

1990 Keepers of the Treasures: Protecting Historic Properties and Cultural Traditions on Indian Lands. U.S. Department of the Interior, National Park Service, Interagency Resources Division, Branch of Preservation Planning. vi + 214 pp.

Powell, Mary Lucas, Patricia S. Bridges, and Ann Marie Wagner Mires (editors) 1991 What Mean These Bones? Studies in Southeastern Bioarchaeology. $\mathrm{xi}+229 \mathrm{pp}$. University of Alabama Press. 